\title{
Design of Family and Child Welfare Policy in Indonesia
}

\author{
hammad Adnan* \\ Political and Government Studies, Universitas Diponegoro, Jl. Prof.H.Soedarto, S.H.Tembalang, Tembalang, Kota Semarang, Jawa \\ Tengah 50275, Indonesia
}

\begin{abstract}
Family is the basis of public welfare. Family welfare determine the children development. Indonesia government ensure family and child welfare of their citizen by applying Child Rights Convention and strengthen some policies. Indonesia government, through Ministry of Social, also arranged PKSA/ Children Welfare Program. This program classify vulnerable child into five cluster, and reach them by three ways: integrated cash aid, social workers, and access to social services. This program targeted no less than 4.3 million children in all region. Though this program were succesfully implemented, but still needed some improvement, such as involvement of local government, recruitment of social workers, and more establishment of LKSA with good facilities and services. PKSA should also be financially sustainable that can reach more children from many families with its whole services.
\end{abstract}

Keywords: Welfare State, Welfare Policy, Family Welfare, Child Welfare, Child Protection

\section{Introduction}

The state is responsible for ensuring the welfare of its citizens. It is known as welfare state concept. Welfare state concept involve fund protection from the state, through the services nor by direct cash on beneficiaries. This policy funded by redistributional taxation that typically includes higher income tax for people with higher income, commonly referred to as progressive taxes[1].

\section{Methodology}

Generally, welfare state concept divided into two models, 1)universal model - with the provisions that including all citizen; 2)selective model - only including those needed it the most. But Gosta EspingAndersen further identified the third model, based on variation (demodification) of social-warranty services[1]. This paper will discuss one of Indonesia's government policy to ensure family and child welfare.

\section{Discussion}

Family is the smallest social unit of community institution. Family is defined as a group of people related by blood, marriage, law (in the case of adoption), common identity as well as lineage and ethnic group[2]. Attention toward family as a smallest social institution begins with the study that social problems are related to family life, thus many social reformers see the family as the basis of public health and welfare.

The concept of welfare not merely defined as prosperity and happiness. Welfare is not only refer to physical fulfill of certain individu nor family as an entity but also their psychological needs. Soetjipto ${ }^{3}$ stated that family welfare is a harmonious circumstances and fulfillment of physical and social needs for family members, without any serious obstacles in surrounding, and able to deal with any family problems together, therefore family's life standards can be realized. This conception means family welfare is a condition that must be created by its family in order to establish prosperous family.

Children, as a family member, is part of society that have important role in determine nation's future. And poverty is a main problem of child vulnerability. Poor family prevent their child's basic needs: health, nutrition, and good education. For addition, stress related to poverty, unemployment, and limited access are increasing child neglection. PPLS/Social Protection Program Data Processing shows that in 2011, 23.4 million children below 16 years old living in poverty and 3.4 million children age 10-17 works as unpaid worker. Based on Child Rights Convention by United Nations, child problems are impact of child's right unfulfillment, consist of 1)civil rights and fundamental freedom, 2)health, nutrition, water, and sanitation, 3)family environment and alternative treatment, 4)education, leisure time, cultural 
activities, and 5)special protection[4]. Thus, family welfare will only achieved if the child protection were assured.

Indonesia government have been showing their commitment to child protection by adopt and strengthen some policies and international law frame that ensuring children's right. In 1990, Indonesia had ratified Child Rights Convention of United Nations. This convention oblige the government to promote the policies and run the action related to child interests, to appreciate children's right in the field of economic, social, culture, civil and politic, and to protect children from bad treatment, exploitation, discrimination, and violation ${ }^{4}$. Nationally, government imposed many policies or Undang-Undang in line with the convention, such as UU No.13 year 2006 about witness and victim protection; UU No.23 year 2006 about population administration; and UU No.21 year 2007 about trafficking eradication; and other acts to decrease rate of child worker and child exploitation. And the current program conducted by Indonesia government is PKSA/ Program Kesejahteraan Sosial Anak / Children Welfare Program.

In recent years, Indonesia had started developing a comprehensive and integrated child protection system focusing on family-based and society-based care. According to welfare state concept, in this case Indonesia following selective model which focusing on the priority of beneficiaries. This system is integrating social, health, education, and justice services, decrease duplication, inefficiency, and fragmented services which aims to improve access into services.

Throwback to 2000, Indonesia had arranged nurturing/orphanage institution and realized the necessity of shift, from agency-care/orphanage into family-based care. This shift partly based on research findings about institutional care in some orphanage. The research indicates that only $6 \%$ of the children in the orphanage were an orphan. The rest are still having parents, but sent by their family to the orphanage institution, in order to get better education. Besides, majority of the child in the orphanage did not get proper care and protection[5]. In 2011, National Standart in Child Care or Standar Nasional Pengasuhan Anak in institution was legalized. This policy support child's right to live with their family or in the family environment, while institutional care considered as last option.

Paradigm shift in promoting right-based and family-based care has translated into some programs including initiative of poverty alleviation and child care, such as cash aid for Ideal Family Program or Program Keluarga Harapan (PKH) which started in 2007, were giving cash aid for poor family with pregnant mother, baby, and school-aged child. And in 2014, 3.2 million poor families had receiveid its $\mathrm{PKH}$ aid. It also known internationally as Program Conditional Cash Transfer[6].

In 2010, PKSA, under the authority of Ministry of Social, was introduced as intervention of child care in secondary and tertiary levels. This program compile cash aid and social services to help risky child or child in critical condition. PKSA was released because Indonesia has many child living in crisis and majority of them living in poverty, not reachable by PKH or other programs, nor requiring any services didn't provided by other programs. Estimated number of vulnerable child that will be handled by PKSA is 4.3 million[7].

PKSA wanted to reach these child with cash aid: 1.5 million rupiah per child per year (in 2014 reduced to 1 million), combined with counseling and caring to child and their family by social worker and/or nurturing institution, which connect the child and their family with basic social services. This approach: integration of cash aid, caring, and social services; made to make positive changes in children and parents/nanny's behavior, with expected impact in enhancement of caring and decrease in percentage of child with social problems[7]. PKSA had impacted on child welfare and protection but not as significant as expected. In the end of 2015, Directory of Child Social Welfare had gave services and social rehabilitation toward 981,747 child in crisis[8].

In fact, Ministry of Social had been trying to transform five sub-program into an integrated model, one PKSA for all. For 2010-2011 period, PKSA had planned to organize these sub-programs centrally. Meanwhile, part of the central fund sent to local government (known as deconcentrated fund) so they can start their own child welfare program similar with PKSA. The next step in 2011, were planned to start integrating central PKSA and local child welfare program. For period 2014-2019, were planned to improve local government's role and contribution. In 2020, local government will be expected to perform most of PKSA intervention, while national government play the supporting role[7].

As a model of effective response for national child welfare and protection, PKSA should be applicable and be a reference model for local: province and city authority and society to give nurturing and protection toward children. Thus, PKSA encompass local government as part of executive structure, along with certain role description of each level. PKSA guide even mentioning that Social Agency in all levels should establish PKSA managing unit in their office. Hence, its estimated that in 2019, local government will have their own capacities to manage PKSA independently using their resources.

In terms of effectiveness, PKSA has showed that its basic approach: combination of cash aid with intensive guide and nurtuting via social worker and child nurturing agencies, which facilitates accesses to social services and promote family-based care; are quite succesfull. If the approach implemented professionally according to guide, it will result positively. This approach increasing utilization of basic social services, intensifying children behavior, interaction with parents/guardian, and contributing on child welfare in the matter of health, nutrition, and education. But PKSA has only 686 social workers for 5.563 Child Social Welfare Agencies/Lembaga 
Kesejahteraan Sosial Anak (LKSA) which implementing PKSA. LKSA has many social workers while most of them have no social worker background. It means, only no more than $10 \%$ PKSA benefit recipients can be reached by whole PKSA: integrated of cash aid, social workers, and access to social services[7].

Based on child-crisis categories, PKSA conducted on 5 sub-program with different target profile. (Can be seen in Figure 1)

\section{Conclusion}

PKSA as Indonesia's system in ensuring children and family welfare are considered succesfull. But many improvement are needed for escalation, such as involvement of local government, recruitment of social workers, and establish more LKSA with good facilities and services. in the future, PKSA can focus on the natural environment by providing open space, sanitation and green environment facilities. PKSA should be financially sustainable that can reach more children from many families. It can be achieved by support from both local and national government. Afterall, PKSA must be able to reach the children with its complete services: integrated cash aid, social workers, and access to social services.

\section{References}

1. B. Setiyono dan M. Adnan, Merancang Model Negara Kesejahteraan yang Tepat Bagi Indonesia Berdasarkan Konsep Esping-Andersen, (2016)

2. Ministry of Gender, Children and Social Protection hana \& UNICEF, Child and Family Wefare Policy, ernment of Ghana, Accra (2015).

3. S. Soetjipto, Pendidikan Kesejahteraan Keluarga, (1992).

4. UNICEF, Convention on the Rights of the Child, UNICEF. [Online]. Available: https://www.unicef.org/ (2014).

5. B. Lumy, Panti Asuhan Sebagai Lembaga Perlindungan Anak. [Online]. Available: http://www.kdm.or.id (2013).

6. Kementerian Sosial, Program Keluarga Harapan. [Online]. Available: https://kemsos.go.id (2017).

7. Kementerian Sosial \& UNICEF, Penilaian Cepat Program Kesejahteraan Anak Sosial, (2015).

\section{Figure Caption}

Figure 1. Five Child Cluster of PKSA 2015

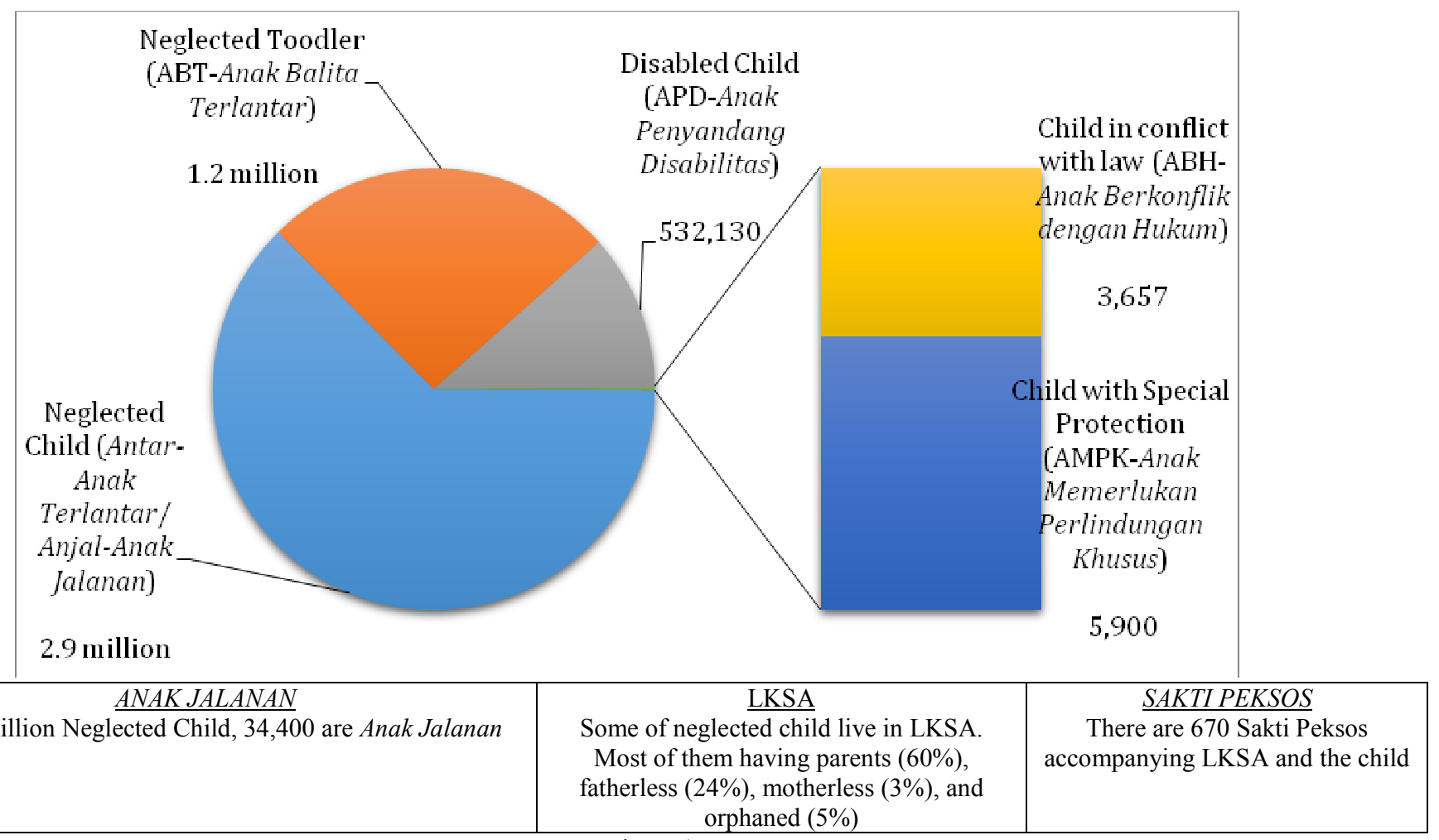

Figure 1 